\title{
Chapter 20 \\ c) Cuba: A Sui Generis Case Study (Communist Proxy)
}

\begin{abstract}
It is illegal and punishable to oppose faith or religious belief to the Revolution, to education or to the fulfilment of the duties of working, to defend the country with arms, to revere its symbols and the other duties established by the Constitution (Article 54: (3) Political Constitution of 1976 of the Republic of Cuba, valid until 1992).

The State recognises, respects, and guarantees religious freedom. In the Republic of Cuba, religious institutions are separate from the State. Different beliefs and religions enjoy equal consideration (Article 8: Political Constitution of 1992 of the Republic of Cuba, valid to this day).
\end{abstract}

Since the socialist revolution, Cuba has exhibited one of the highest social indicator scores in Latin America (e.g. health, literacy, and personal safety) (Feinberg, \& Piccone, 2014; Gold, 2015; United Nations Development Programme-UNDP, 2016; Vekemans \& Segundo, 1963, p. 83). However, its communist regime has made Cuba the third most hostile country to economic and political freedom worldwide (after North Korea and Venezuela) (Miller \& Kim, 2017; Freedom House, 2016). On balance, however, the Cuban social progress index is one of the lowest in Latin America (Porter et al., 2015).

The religious overview is as contradictory as Cuba's social indicators. Historically, direct political influence and formal participation in religion have been low compared to most Latin American countries, even from before the Cuban Revolution. However, widespread religiosity and syncretism strongly permeate religious and secular belief systems in Cuba. Consequently, the institutional influence of religion has been relatively weak compared to the pervasive cultural influence of religion in Cuba (Crahan, 2017, pp. 386, 388; Crahan, 1979, p. 159).

The overall indifference to institutionalised religion in Cuba stems from anticolonial/anti-imperial sentiments. The Roman Catholic Church-State has been perceived as tied to colonial Spain. Protestant churches have in turn been linked to US

\footnotetext{
Supplementary Information The online version of this chapter (https://doi.org/10.1007/978-3-
} 030-78498-0_20) contains supplementary material, which is available to authorized users. 
interests. For instance, the Roman Catholic hierarchy strongly opposed Cuba's independence from Spain, and the US government recommended that US churches ought to use humanitarian aid to promote democracy in Cuba (Crahan, 1979, p. 159; Goldenziel, 2009, p. 206; Ramírez, 2009, p. 169).

The Cuban Revolution impacted the institutional strength of religion (i.e. by abolishing Church privileges, reducing formal membership, and spreading secular education). However, the level of belief among the Cuban population maintained remarkably stable from the 1950s to the present (ca. 75 to 85\%) (Crahan, 2017, p. 390).

\subsection{Colonial Times Until the First Half of the Twentieth Century}

As in the rest of Latin America, Spanish colonisation introduced Roman Catholicism in Cuba. Consequently, the Catholic Church has always had a strong presence in Cuba, and has formed a complex relationship with the political establishment (Contreras, 2013, p. 177; Ramírez, 2009, p. 167).

Independence from Spain (1898) and relations with the USA led to an influx of Protestant missionaries. As a result, several Protestant denominations have been installed in Cuba since the late nineteenth-century, including Methodist, Baptist, Lutheran, Adventist, Presbyterian, and Quaker (Contreras, 2013, p. 178; Ramírez, 2009, p. 171).

Before the Revolution, the Roman Church-State did not have a strong influence in Cuba, unlike in most Latin American countries (Goldenziel, 2009, p. 182; Crahan, 2017, pp. 386, 388; Crahan, 1979, p. 159; Ramírez, 2009, p. 171). Nevertheless, the Roman Church-State privileged de facto or de jure relations with the government, thus enforcing the hegemonic power exerted by Rome until the Cuban Revolution. For instance, the state obliged Protestant churches to register officially, while the Roman Church-State was exempt from such an obligation (Ramírez, 2009, p. 171). Such privileges promoted elitism and created a highly non-egalitarian pre-revolutionary society (like in most Latin American countries) (Crahan, 1979, p. 170).

\subsection{The Revolution: 1960s to the Present}

Among other factors, the relative weakness of the Roman Church-State in Cuba provided opportunities for liberals, US Protestants, and communists, and ultimately led to the Revolution. Naturally, Protestants were more progressive and less counterrevolutionary than Roman Catholics (Crahan, 1979, pp. 159, 170, 172).

When the revolutionary regime adopted Marxism and forged ties with the Soviet Bloc, it adopted an atheistic constitution and became hostile to any form of religion. 
The law on education gave the state the exclusive right to build schools and provide education. Private schools became state property. This severely affected religious and, above all, Roman Catholic schools, which had outnumbered other types of schools before the Revolution (Contreras, 2013, p. 179; Crahan, 1979, p. 179).

The general reaction of Cuban society to the adoption of Marxism in the 1960s was negative, due to the religious implications. Accordingly, the hostilities to religion led to exiling Roman Catholic priests and Protestant pastors. Properties were seized and dozens of clerics and laypersons were tortured (Crahan, 1979, p. 174; Ramírez, 2009, p. 173).

In the 1970s and 80s, the Cuban Revolution stimulated other social movements in Latin America, including Liberation Theology within Roman Catholicism and later also in Protestantism (Berges \& Cárdenas, 1993; Ramírez, 2009). Fidel Castro, Cuba's communist leader for almost five decades, publicly expressed a positive view of religion for the first time in 1985. Castro admitted that religion could also have the potential to alter reality, revolutionise a nation, end oppression, and restore justice (Castro \& Betto, 2006, p. 5).

The collapse of the Soviet Union in the early 1990s resulted in a severe economic crisis in Cuba, (known as the "special period") (Goldenziel, 2009, p. 202). This, in turn, led to a revival of religious activity, which was closely linked to the unfolding socioeconomic crisis during the 1990s (Ramírez, 2009, p. 174). This fairly typical phenomenon corroborates the theory of existential security (Norris \& Inglehart, 2004). Accordingly, Afro-Cuban and Pentecostal religions have witnessed rapid growth, like other faiths in Cuba (Goldenziel, 2009, p. 202).

The Cuban regime responded to the crisis by implementing a new constitution (1992), which included religious freedom and the substitution of an atheist state with a secular one (Goldenziel, 2009; Contreras, 2013). Granting greater religious freedom was part of a strategic political ploy to strengthen the socialist regime (Goldenziel, 2009).

Three aspects are worth mentioning in this respect:

1. The collapse of the Soviet Union and the crucial role of the Roman Church-State at the time. The Cuban regime realised the value of an important political tradeoff: counting on Rome as an ally (not as an enemy) to maintain dictatorship. Thus, greater religious freedom allowed the regime to cultivate relations with the Catholic hierarchy (Goldenziel, 2009; Crahan, 2017; Contreras, 2013);

2. Religious freedom helped the regime to legitimise itself in a religious society (whose religiosity underwent a revival after the 1990s crisis) (Goldenziel, 2009);

3. Constitutional religious liberty permitted the Cuban regime to circumvent US trade regulations, thus enabling economic aid to flow into Cuba via religious groups. Furthermore, the Cuban establishment took various measures to avoid US-like Protestant opposition by co-opting and regulating the Council of Churches through a clientelistic-corporatist scheme. This mechanism allows Council members to benefit from increased political power while limiting their autonomy to censure the government (Goldenziel, 2009). 
After Cuba opened itself in 1991, Afro-Cuban organisations also came into the corporatist fold (Goldenziel, 2009, p. 201).

Finally, the break between the Roman Church-State and the Cuban government after the Revolution demonstrated Rome's ability to survive and adapt to unfavourable conditions (Contreras, 2013, p. 177). The Cuban revolution showed the Roman Church-State that it could include Marxist elements in its dialectic and thus support left-wing dictators to gain political revenue. Consequently, despite initial resistance to liberation theology, the Roman Church-State hierarchy accepted this to a certain extent, as an element integral to upholding its hegemony (see Sect. 10.4.1.4.1).

Although the Catholic Church-State still does not achieve the same power in Cuba as in other Latin American countries, it still has the necessary elements to achieve this goal. It relies on a centuries-long legacy and on a well-consolidated hierarchical structure, from the Vatican down to Cuban priests and believers (Contreras, 2013, p. 193). Indeed, the Roman Catholic Church has the richest and most ancient, extensive, and organised presence of any religion, both in Cuba and worldwide (Goldenziel, 2009, p. 195).

In turn, the Protestant experience in Cuba largely confirms the findings of various scholars (e.g. Helmsdorff, 1996; Schäfer, 2006; and Martin, 1999) for other Latin American countries: The Council of Churches (which represents most Protestant denominations) has adopted the same established practices of corporatism and clientage (Goldenziel, 2009).

\subsection{Religion Adherents and Prominent Syncretism in Cuba}

Protestants have amounted 3 to 6 percent of the Cuban population according to different estimates (Goldenziel, 2009, p. 206; Crahan, 2017, p. 397). About $70 \%$ of Cubans claim to practice spiritism. Also, roughly two-thirds of Cubans have traditionally identified as Roman Catholics, thus indicating the high degree of syncretism in the country (Crahan, 2017, p. 384; Hearn, 2008, p. 17; see also Sect. 10.5.1.1.2).

\subsection{Empirical Analysis and CDA for Cuba (Corruption)}

\subsubsection{Textual Analysis (Theological)}

None of the interviewed stakeholders refers directly to a Christian (i.e. biblical) principle of corruption potentially linked to the moral law. However, the Protestant Methodist Pastor (h) mentioned the role of the Protestant (Methodist) Church in 
Table 20.1 Principles of corruption according to stakeholders interviewed in Cuba (Source: Author's figure)

\begin{tabular}{|c|c|}
\hline \multicolumn{2}{|l|}{ Corruption } \\
\hline Stakeholder & Fundamental principles identified (interviews) \\
\hline The Holy Bible & $\begin{array}{l}\text { "Keep thee far from a false matter; and the innocent and righteous } \\
\text { slay thou not: for I will not justify the wicked. And thou shalt take } \\
\text { no gift: for the gift blindeth the wise, and perverteth the words of } \\
\text { the righteous" (King James Bible, 1769, Exodus 23:7-8). }\end{array}$ \\
\hline $\begin{array}{l}\text { b) Roman Catholic } \\
\text { Priest } 2 .\end{array}$ & $\begin{array}{l}\text { "Corruption comes from below, from people with limitations. } \\
\text { Cuban people survive from the 'black bag' [black market and } \\
\text { rubbish]. And there is a struggle to see whom to damage, [which is] } \\
\text { typical of the black market that is unscrupulous. And that struggle } \\
\text { will end when people have the opportunity to meet their needs in } \\
\text { another [legal] way". }\end{array}$ \\
\hline $\begin{array}{l}\text { e) Roman Catholic } \\
\text { Theologian }\end{array}$ & $\begin{array}{l}\text { "As people live badly, they cheat on the state. And the Church } \\
\text { [Catholic] says this is not a sin. Why so? Because it's Fair Com- } \\
\text { pensation, a Catholic doctrine. The state has taken the properties of } \\
\text { the people; it is fair that people seek their compensation. In this } \\
\text { sense, it's okay to cheat on the state or to steal like Robin Hood. } \\
\text { In 1961, the relations between church and state were impossible. } \\
\text { The Church was the largest landowner in Cuba and then the } \\
\text { US. The Church supported the revolution and thought its lands } \\
\text { would be protected. That was not the case. } \\
\text { Now, the closeness between the pope and state are necessary } \\
\text { because it suits the state and it is convenient for the Church. The } \\
\text { Church wants to receive privileges and status, and the state wants to } \\
\text { show piousness and social sensitivity. It is like a 'Mafia kiss' ('un } \\
\text { beso de mafiosas')". }\end{array}$ \\
\hline $\begin{array}{l}\text { f) Protestant Pastor } \\
1 \text { (Pentecostal) }\end{array}$ & $\begin{array}{l}\text { "Christians [Protestants] also do unlawful things but to a lesser } \\
\text { extent than the rest. Christians [Protestants], in general, do not } \\
\text { party; do not drink alcohol; are not adulterers. They do not commit } \\
\text { idolatry. We are committed to God and keep a high [moral] stan- } \\
\text { dard here in Cuba. } \\
\text { [But] in Cuba, you live outside the law. Cubans think with their } \\
\text { bellies. The US has the Cuban Adjustment Act (dry and wet feet). I } \\
\text { hope that in heaven there will be a Cuban Adjustment Act, too } \\
\text { (laughs)". }\end{array}$ \\
\hline $\begin{array}{l}\text { g) Protestant Pastor } \\
2 \text { (Adventist) }\end{array}$ & $\begin{array}{l}\text { "There is a culture of 'to solve' in Cuba: in society, in general in the } \\
\text { population. The concept of "theft" has been distorted and softened } \\
\text { by 'to solve"". }\end{array}$ \\
\hline $\begin{array}{l}\text { h) Protestant Pastor } \\
3 \text { (Methodist) }\end{array}$ & $\begin{array}{l}\text { "[...] Nowadays, what is said is not done. No one abides by } \\
\text { the laws. } \\
\text { The difference between before the revolution and now is that now } \\
\text { corruption is widespread and before it was not. } \\
\text { If we go out walking in the street, I can give you 10,000 examples } \\
\text { of corruption. For example, in that little corner, in that cafe, most of } \\
\text { their products are not legal. They are not selling what they have to } \\
\text { sell, and so on. } \\
\text { Or, for example, if we go to a flea market selling agricultural } \\
\text { products, they do not measure a fair weight. They are trying to } \\
\text { deceive people and are burdening the system. They are evading }\end{array}$ \\
\hline
\end{tabular}


Table 20.1 (continued)

\begin{tabular}{|c|c|}
\hline \\
\hline \multirow[t]{2}{*}{ Stakeholder } & Fundamental principles identified (interviews) \\
\hline & $\begin{array}{l}\text { taxes, and so on. } \\
\text { If we go to a government institution or we go to a ticket agency } \\
\text { there will be "no tickets". But if you pay a bribe of } \$ 20 \text { or } \$ 10 \text {, } \\
\text { regardless of the destination, you can get a ticket. This has become } \\
\text { a culture, a culture of corruption. } \\
\text { I am an evangelical [Methodist], and we evangelicals are very } \\
\text { concerned about these issues. For us, in our Church, when we do an } \\
\text { event and have to buy food, we think twice, because it is a matter of } \\
\text { conscience and we know where the products come from". }\end{array}$ \\
\hline $\begin{array}{l}\text { k) Non-Christian (atheist, } \\
\text { agnostic) (Academic) }\end{array}$ & $\begin{array}{l}\text { "You have to pay more [a bribe] for a government certification with } \\
\text { good spelling. Otherwise, they will give you with bad spelling, } \\
\text { sometimes on purpose. [Also] Many Cubans watch television } \\
\text { through an illegal package. Cubans normally are seeking to break } \\
\text { the law and do what they want. } \\
\text { Corruption was minimal after the revolution, and now it has } \\
\text { increased. Buying a car was a reward only for good workers". }\end{array}$ \\
\hline $\begin{array}{l}\text { m) Employee, Independent } \\
\text { citizen }\end{array}$ & "Unnecessary bureaucracy and corruption is eating away Cuba". \\
\hline n) Tourism professional & $\begin{array}{l}\text { Here it is common to evade the law and to pay bribes to get things } \\
\text { done. Otherwise, you could wait all your life without anything } \\
\text { happening. } \\
\text { Here we have a saying: 'The government pretends to pay me, and I } \\
\text { pretend to work' (El gobierno hace como que me paga y yo hago } \\
\text { como que trabajo). }\end{array}$ \\
\hline p) Government official & $\begin{array}{l}\text { "In Cuba, we now have 'indirect democracy,' which means that } \\
\text { you vote for representatives who vote for governors. Here, Cubans } \\
\text { say that 'Fidel gives everything' [to the people] and the state is } \\
\text { infallible, like God.' However, the 'new man' whom Che Guevara } \\
\text { dreamt of has become the corrupt Cuban and a hooker (Jinetera). } \\
\text { Today there are very low moral standards here. Immorality is rife, } \\
\text { Jineteras. Rampant state corruption and everywhere else. Unnec- } \\
\text { essary bureaucracy. But before the Revolution, there was much } \\
\text { more corruption, aristocracy and Catholicism. } \\
\text { To whom shall the needy look? Shall they look to the government } \\
\text { or the church? They are both immoral, and if we focus on them, we } \\
\text { will become more immoral. We can be better and lower corruption } \\
\text { only by looking at God's perfection." }\end{array}$ \\
\hline
\end{tabular}

Note: No quantitative data on competiveness is available for Cuba and little qualitative data resulted from coding prosperity.

preventing cheating from spreading in Cuban society. This is indirectly in line with Exodus 23 (King James Bible, 1769) (Table 20.1).

The Roman Catholic Theologian (e) mentions the Roman Catholic doctrine of Fair Compensation, which "justifies" stealing or cheating in certain situations (like 
Robin Hood). This doctrine is opposed to Exodus 23 (King James Bible, 1769) (Table 20.1). Likewise, the "necessary Mafia kiss" between church and state is against another biblical principle: "Render therefore unto Caesar the things which are Caesar's; and unto God the things that are God's" (King James Bible, 1769, Matthew 22:21).

\subsubsection{Analysis of Discourse Practice (Theoretical Triangulation)}

The atheist, socialist legal principle of the "goodness of humankind" (Berman 2003, p. 18) resembles Roman Catholic natural law, in that it trusts the human capacity to discern good from evil (Selling, 2018, p. 9; Gula, 2002, pp. 120-21). Arruñada (2010) explains that Roman Catholicism enhances corruption due to the relativistic contents of its moral code and its dubious enforcement mechanisms (p. 895). These statements are valid in Cuban society, as exemplified above in various ways: (1) by the practice of Fair Compensation (see Roman Catholic Theologian (e)); (2) by the Protestant Methodist Pastor's comments on cheating and stealing (h); (3) by the common Cuban proverb "The government pretends to pay me, and I pretend to work" (Tourism professional (n)); and (4) by the non-Christian atheist's example of cheating to pay a bribe (k).

\subsubsection{Analysis of Social Practice: Law and Institutions}

The Tourism professional (n) highlights the evasion of laws and payment of bribes as the natural way of life in Cuba. Likewise, the non-Christian atheist (k) refers to similar examples of breaking the law. Such examples are consistent with the systematic separation of law, culture, and morals common in most Latin American countries (Mockus et al., 2012; see also Sect. 10.3.1.2).

The Government Official (p) argues in a similar direction and indirectly challenges the socialist legal tradition (Sect. 8.3.4.7). His criticism refers to what Marxist theory calls the ideal "new man". In practice, however, this has produced a corrupt Cuban and the hooker (Jinetera). Stakeholder (p) expands this perspective, observing that low moral standards pervade the government and the Church. What remains is the need to consider God's perfection the sole point of reference. 


\section{References}

Arruñada, B. (2010). Protestants and catholics: Similar work ethic, Different social ethic. The Economic Journal, 120(547), 890-918.

Berges, J., \& Cárdenas, R. (1993). El pastorado protestante y la Nueva Teología Cubana. In J. Berges \& R. Cárdenas (Eds.), La religión. Estudio de especialistas cubanos sobre la temática religiosa. La Habana: Política.

Berman, H. (2003). Law and revolution II: The impact of the protestant reformations on the western legal tradition. Cambridge, London: Harvard University Press, Belknap Press.

Castro, F., \& Betto, F. (2006). Fidel and religion: Fidel Castro in conversations with Frei Betto on Marxism and Liberation Theology (2nd edn, M. Todd, Trans.). Melbourne: Oceana Press (Original work published 1985).

Contreras, D. (2013). Iglesia Católica y estado en la República de Cuba: Pasado y presente de sus relaciones Catholic Church and State in Cuba: Past and present relationships. América Latina Hoy, 63, 177-195.

Crahan, M. E. (1979). Salvation through Christ or Marx: Religion in revolutionary cuba. Special issue: The church and politics in Latin America. Journal of Interamerican Studies and World Affairs, 21(1), 156-184.

Crahan, M. E. (2017). Cuba: Religion and civil society. Social Research, 84(2), 383-405.

Feinberg, R. E., \& Piccone, T. (2014). Cuba's economic change in comparative perspective. Latin American Initiative at Brookings; Center for the Study of the Cuban Economy (CEEC), University of Havana; and Center for Research on the International Economy (CIEI), 129. Retrieved from https://www.brookings.edu/wp-content/uploads/2016/06/Cubas-EconomicChange-English-web-1.pdf

Freedom House. (2016). Freedom in the world 2016. Anxious dictators, wavering democracies: Global freedom under pressure. Washington, DC: Freedom House.

Gold, M. (2015). People and state in socialist Cuba. Ideas and practices of revolution. New York: Palgrave Macmillan.

Goldenziel, J. (2009). Sanctioning faith: Religion, state, and U.S.-Cuban relations. Journal of Law and Politics, 25(179), 179-210.

Gula, R. M. (2002). Reason informed by faith-foundations of catholic morality. Paulist Press.

Hearn, A. H. (2008). CUBA religion, social capital, and development. Durham and London: Duke University Press.

Helmsdorff, D. (1996). Participación política evangélica en Colombia. (D. A. Bidegain, Ed.) Bogotá: Universidad de los Andes. Departamento de Historia. Tesis de Grado.

King James Bible. (1769). The Holy Bible, King James Version. Cambridge Edition: 1769. Scripture quotations from The Authorized (King James) Version. Rights in the Authorized Version in the United Kingdom are vested in the Crown. Reproduced by permission of the Crown's patentee, Cambridge University Press.

Martin, D. (1999). The evangelical upsurge and its political implications. In P. Berger (Ed.), The desecularization of the world (pp. 37-49). Washington, DC: Ethics and Public Policy Center and Wm. B. Eerdmans Publishing Co.

Miller, T., \& Kim, A. B. (2017). Index of economic freedom. Washington, DC: The Heritage Foundation. Retrieved from http://www.heritage.org/index

Mockus, A., Murraín, H., \& Villa, M. (2012). Antípodas de la violencia: Desafíos de cultura ciudadana para la crisis de (in)seguridad en América Latina. Washington, DC: Banco Interamericano de Desarrollo.

Norris, P., \& Inglehart, R. (2004). Sacred and secular: Religion and politics worldwide. New York: Cambridge University Press.

Porter, M., Stern, S., \& Green, M. (2015). Social progress index 2015. Retrieved from https://www. socialprogress.org $/ ? \mathrm{tab}=2 \&$ code $=\mathrm{NOR}$

Ramírez, C. J. (2009). Laïcité, liberté de religion et État laïque. Les étapes de la laïcisation cubaine. Archives de Sciences Sociales des Religions, 54(146), 157-182. 
Schäfer, H. (2006). »Die« Pfingstbewegung in Lateinamerika...? Zur Untersuchung des Verhältnisses zwischen religiöser Praxis und gesellschaftlichen Strukturen. Zeitschrift für Religionswissenschaft, pp 53-82.

Selling, J. A. (2018). Reframing catholic theological ethics: Summary and application (A. Abram, Ed.). Religions, 8(203), 5-13.

United Nations Development Programme-UNDP. (2016). Human Development Index (HDI). Retrieved from http://hdr.undp.org/en/content/human-development-index-hdi

Vekemans, R., \& Segundo, J. L. (1963). Essay of a socio-economic typology of the Latin American countries. En E. de Vries, J. Medina, \& B. Higgins (Eds.), Social aspects of economic development in Latin America (Conference: Expert Working Group on Social Aspects of Economic Development in Latin America., Vol. 1). UNESCO. Retrieved from https:// unesdoc.unesco.org/ark:/48223/pf0000054509.locale=es

Open Access This chapter is licensed under the terms of the Creative Commons Attribution 4.0 International License (http://creativecommons.org/licenses/by/4.0/), which permits use, sharing, adaptation, distribution and reproduction in any medium or format, as long as you give appropriate credit to the original author(s) and the source, provide a link to the Creative Commons license and indicate if changes were made.

The images or other third party material in this chapter are included in the chapter's Creative Commons license, unless indicated otherwise in a credit line to the material. If material is not included in the chapter's Creative Commons license and your intended use is not permitted by statutory regulation or exceeds the permitted use, you will need to obtain permission directly from the copyright holder. 